TARBIYATUNA: Kajian Pendidikan Islam

Volume 3 Nomor 2 Tahun 2019

Print ISSN : 2597-4807

Online ISSN : 2622-1942

\title{
PENGARUH METODE PROBLEM SOLVING \\ TERHADAP KEMAMPUAN PEMAHAMAN KONSEP SOAL CERITA \\ MATERI VOLUME BALOK \\ SISWA KELAS V MI AN-NASHRIYAH LASEM REMBANG
}

\author{
Noprastiyaning Ismu Salamah ${ }^{1}$, Zainal Arifin ${ }^{2}$ \\ 1,2 Pendidikan Guru Madrasah Ibtidaiyah STAI Al-Anwar Sarang Rembang, \\ e-mail: ${ }^{1}$ noprastiya16@gmail.com, ${ }^{2}$ zavinabivastavuz@gmail.com
}

\begin{abstract}
This research is motivated by students difficulties in understanding and solving problems related to story-shape questions in mathematic. The principal issues are analyzed in this study are: to determine influence problem solving method towards on the ability to understand the concept of the story of the fifth grade students of MI An-Nashriyah Lasem, Rembang. The research is experimental elaborated control group pretest posttest design. The study was conducted on 62 students using test, observation and documentation instruments. Based on the results of independent samples t-test showed the influence of problem solving methods on the ability to understand the concept of story problems with a significance level of 0.05>0.000 indicating an influence.
\end{abstract}

Keywords: problem solving method, concept of story, box volume

\begin{tabular}{|c|c|c|}
\hline Accepted: & Reviewed: & Publised: \\
Juli 262019 & Agustus 5 2019 & September 30 2019 \\
\hline
\end{tabular}

\section{A. Pendahuluan}

Pendidikan di Indonesia dapat ditempuh dengan menjalani proses pembelajaran. Proses pembelajaran merupakan bagian dari suatu sistem pendidikan. Pencapaian standar proses untuk meningkatkan kualitas proses pembelajaran dapat dimulai dari analisis setiap komponen agar mempengaruhi proses pembelajaran yang dilakukan di dalam kelas. Salah satu caranya yaitu dengan pemilihan strategi pembelajaran yang tepat untuk siswa. Pemilihan ini sangat penting, sehingga guru dapat memilih kegiatan pembelajaran yang paling efektif dan efisien untuk menciptakan pengalaman belajar yang baik. Dengan adanya strategi pembelajaran yang baik, siswa dapat meningkatakan pemahaman dari kegiatan pembelajaran yang dilakukannya.

Menurut Hamdani (2011:72) peristiwa belajar yang disertai proses pembelajaran akan lebih terarah dan sistematis dari pada belajar yang hanya dari

This work is licensed under Creative Commons Attribution Non Commercial 4.0 International License Available iaiibrahimy.ac.id 
kehidupan sosial di masyarakat. Selama belajar, pemrosesan berarti menangkap informasi baru yang sedang diajarkan. Masing-masing individu memilki kamampuan pemahaman yang berbeda-beda. Pemahaman awal dimulai, maka proses aktif berkelanjut menjadi kunci bagi otak para siswa untuk menyimpan konsep baru kedalam ingatan jangka panjang. Maka perlu adanya proses masuknya informasi baru dan menyusun kesempatan bagi siswa untuk memprosesnya, sehingga tercipta timbal balik antara siswa dengan guru dengan model pancingan yang diberikan.

Matematika merupakan salah satu mata pelajaran yang paling dekat dengan kehidupan sehari-hari siswa. Ini berarti matematika berperan sangat penting dalam kehidupan siswa. Bahkan pengajarannya mulai dari awal sekolah dasar sampai perguruan tinggi. Dalam pembelajaran matematika di tingkat sekolah dasar, diharapkan terjadi penemuan kembali (inquiry). Pada pembelajaran matematika ini harus ada keterkaitan pengalaman belajar siswa dengan konsep yang akan diajarkan oleh guru, karena dalam pembelajaran matematika konsep satu dengan yang lain saling terkait. Siswa harus memahami dengan tepat konsep dasar sehingga tidak membingungkan saat penerapan konsep lain (Heruman, 2017: 4). Jadi pembelajaran matematika menekankan pada pemahaman konsep yang tepat. Dalam menganalisa berbagai varian soal, siswa rata-rata menganggap matematika adalah pelajaran yang sulit, ribet, dan membosankan.

Analisis variasi soal matematika menjadi permasalahan yang sering dialami siswa, salah satunya yaitu mengerjakan soal cerita dalam pembelajaran matematika. Menurut Muhsetyo (Winarni \& Harmini, 2017: 120-122) soal cerita merupakan soal matematika yang dinyatakan dalam serangkaian kalimat. Masalah yang disajikan dalam soal cerita tidak dapat dikerjakan secara prosedural, menuntut adanya penyelesaian secara rumit dan lebih luas. Hal yang dapat dilakukan siswa adalah dengan mengoptimalkan pemahaman soal terlebih dahulu, mengidentifikasi persoalan, lalu siswa dapat menyusun strategi yang tepat untuk mengerjakannya. Dengan kata lain, diperlukan adanya pemecahan masalah dari persoalan yang disajikan tersebut.

Berdasarkan hasil wawancara yang dilakukan peneliti dengan guru kelas $\mathrm{V}$ MI An-Nashriyah Lasem, Rembang terdapat beberapa kendala yang dialami dalam mata pelajaran matematika, diantaranya: (1) Beberapa siswa belum memahami konsep operasi hitung matematika dengan benar, sehingga masih belum teliti dalam pengerjaan soal matematika; (2) Pendekatan pembelajaran saintifik yang digunakan oleh guru masih bersifat trial and error, di mana guru masih mencari dan mencoba metode-metode yang sejalan dengan pendekatan saintifik. Hal ini dikarenakan Kurikulum 2013 baru diberlakukan pada madrasah tersebut; (3) 
Siswa malas untuk membaca soal cerita matematika yang berkaitan dengan kehidupan sehari-hari siswa. Akibatnya, siswa kurang memahami isi atau kandungan soal yang diberikan guru dalam mengerjakan soal cerita matematika; (4) Kemampuan pemahaman soal cerita matematis relatif kurang, sehingga dalam menjawab berbagai soal cerita yang diberikan oleh guru, siswa lebih memilih untuk mengerjakan soal yang sudah jadi dari pada harus mengerjakan soal cerita. Pemahaman tentang konsep relatif rendah dan siswa cenderung hanya menghafalkan rumus-rumus matematika tanpa mereka mengetahui konsep untuk mengerjakan soal matematika dengan tepat; (5) Siswa masih sering kebingunan dalam mengerjakan soal-soal yang berkaitan dengan kehidupan sehari-hari siswa (soal cerita) dan belum bisa menyelesaikan dengan tahap-tahap atau langkahlangkah yang benar, sehingga guru masih perlu membimbing pengerjaan soal cerita matematika siswa; (6) Siswa belum memahami kegunaan dan aplikasi soal cerita matematika dalam kehidupan sehari-hari siswa.

Salah satu model pembelajaran yang coba ditawarkan untuk menyelesaikan permasalahan kemampuan pemahaman siswa dalam variasi soal matematika adalah metode problem solving. Metode ini dapat membuat siswa berfikir secara langsung, kritis, berdiskusi, berkelompok, berkerja sama menyelesaikan suatu masalah. Siswa mendapatkan informasi dari kelompoknya serta dapat mengkomunikasikan berbagai macam pemikiran dari teman kelompoknya. Dari tahap-tahap pembelajaran yang dilakukan dalam pembelajaran memungkinkan adanya pemahaman dari masing-masing siswa. Masalah-masalah yang ditampilkan dapat berupa masalah yang siswa alami di sekitarnya.

Berdasarkan uraian dari permasalahan di atas, peneliti termotivasi untuk melakukan penelitian yang bertujuan untuk mengetahui penggunaan metode problem solving dalam pembelajaran matematika dan pengaruhnya terhadap kemampuan siswa dalam memahami konsep soal-soal matematika terkait volume balok yang disajikan dalam bentuk cerita.

\section{B. Metode penelitian}

Penelitian ini dilakukan di kelas V pada Madrasah Ibtidaiyah An-Nashriyah yang terletak di Jl. Sunan Bonang KM. 01 Desa Ngemplak Kecamatan Lasem Kabupaten Rembang. Penelitian dilaksanakan pada Tahun Pelajaran 2018/2019, Semester II (Genap).

Jenis penelitian yang digunakan adalah eksperimen dengan menggunakan desain Control Group pretest-posttest yang merupakan bagian dari eksperimen murni (true eksperimental). Jenis sampel yang diambil adalah purposive sampling, yaitu teknik pengambilan sampel dengan pertimbangan tertentu. Kelas V-A 
sebagai kelas kontrol dan kelas V-C sebagai kelas eksperimen. Jumlah subjek penelitian kelas V-A dan V-C sebanyak 62 siswa.

Teknik pengumpulan data primer menggunakan tes. Observasi dan dokumentasi digunakan untuk mengumpulkan data sekunder. Tes terdiri dari pretest dan posttest. Tes digunakan untuk mengumpulkan data terkait kemampuan pemahaman konsep soal cerita. Soal yang digunakan divalidasi melalui uji validitas dan reliabilitas instrumen. Observasi digunakan untuk mendapatkan data pendukung terkait kegiatan pembelajaran dengan metode problem solving. Dokumentasi digunakan untuk mengumpulkan data pendukung yang berkaitan dengan administrasi pembelajaran.

Analisis data menggunakan aplikasi SPPS 22.0 dengan menggunakan uji prasyarat uji normalitas menggunakan kormogorov-smirnov dan uji homogenitas. Pengujian hipotesis menggunakan independent samples t-test untuk mengetahui pengaruh metode problem solving terhadap kemampuan pemahaman konsep soal cerita.

\section{Hasil Penelitian dan Pembahasan}

\section{Problem Solving}

Pembelajaran merupakan salah satu bagian penting dalam dunia pendidikan. Bukan memberikan apresiasi berlebihan namun telah difahami bahwa proses pembelajaran sangat menentukan ketercapaian tujuan pendidikan. Belajar dalam konteks untuk menghadapi berbagai tantangan kehidupan global yang merajalela perlu dilakukan upaya-upaya pencarian watak pembelajaran yang ideal, sehingga dapat membantu para pembelajar untuk memecahkan berbagai masalah (problem solving) yang dihadapi dalam kehidupan nyata sehingga pembelajaran lebih bermakna.

Problem solving merupakan mencari atau menemukan cara penyelesaian (menemukan pola, aturan atau algoritma). Dalam pelaksanaan metode problem solving, tahapan awal yang dilalui siswa meliputi penyajian masalah, mengidentifikasi pola permasalahan, mengeksplorasi, menginvestigasi, menduga dan akhirnya menemukan solusi dari masalah yang disajikan. Siswa juga dapat berkelompok untuk mendiskusikan permasalahan tersebut (Ngalimun, 2017: 331). Fokus pembelajaran dari masalah tersebut dapat diselesaikan siswa melalui kerja kelompok sehingga dapat memberikan pengalaman-pengalaman belajar yang beragam meliputi kerjasama, interaksi antarkelompok, disamping pengalaman yang berhubungan dengan pemecahan masalah tersebut, sehingga dapat meningkatkan pemahaman siswa tentang apa yang dipelajari agar dapat diterapkan dalam kondisi nyata pada kehidupan sehari-hari. Masalah yang dipilih 
dapat menjadi fokus pembelajaran sehingga siswa tidak hanya mempelajari tentang konsep-konsep yang ada tetapi juga mempelajari tahapan metode ilmiah untuk menyelesaikan masalah tersebut (Ngalimun, 2017: 172-173).

Menurut Hamdani (2011: 86), metode problem solving merupakan metode dalam pelaksanaan kegiatan pembelajaran dengan jalan awal melatih siswa menghadapi berbagai masalah yang dapat dipecahkan pribadi maupun masalah kelompok untuk dipecahkan sendiri atau secara bersama-sama. Orientasi pembelajarannya adalah penemuan (inquiry) yang pada dasarnya adalah pemecahan masalah yang disajikan.

Sedangkan menurut Djamarah dan Zain (2014: 91), metode problem solving bukan sekedar metode mengajar, tetapi juga metode berpikir, sebab dalam problem solving dapat menggunakan metode-metode lainnya yang dimulai dengan mencari data sampai kepada menarik kesimpulan.

Jadi, metode problem solving atau pemecahan masalah adalah suatu metode belajar yang digunakan untuk melatih siswa melakukan pemahaman pengetahuan secara bertahap melalui pengalaman, konsep berfikir, serta memahami situasi yang ada di sekitarnya. Problem solving merupakan metode yang tepat untuk memahami konsep-konsep pengetahuan khususnya mata pelajaran matematika guna mengetahui aplikasi masalah matematika di kehidupan sehari-hari.

Karakteristik dalam pemecahan masalah, siswa mempunyai tanggung jawab untuk menyusun sendiri strategi dan pemecahan masalah, hal ini dapat diterapkan dengan penggunaan strategi yang tepat, salah satunya dengan kelompok-kelompok kecil sehingga seluruh siswa terlibat dalam proses pembelajaran. Guru menuntun upaya siswa dengan mengajukan pertanyaan dan memberikan dukungan pengajaran lain saat siswa siswa berusaha memecahkan masalah. Karakteristik awal ini sangat penting dan menuntut keterampilan serta pertimbangan yang sangat professional untuk memastikan kesuksesan pembelajaran. Guru dapat melakukan dukungan maupun bimbingan, namun harus seimbang tidak kurang maupun berlebihan agar siswa mendapat banyak pengalaman dalam pemecahan masalah yang sedang diselesaikan (Eggen \& Kauchak, 2016: 307)

Metode problem solving ini dapat digunakan dalam pembelajaran matematika. Langkah yang tepat dalam pembelajaran dapat membuat siswa memahami materi yang disampaikan oleh guru. Adapun langkah-langkah metode problem solving sebagai berikut (Trianto, 2010: 98):

a. Orientasi siswa pada masalah.

Guru memberikan penjelasan tujuan pembelajaran yang dilakukan, menjelaskan beberapa sarana pembelajaran yang dibutuhkan. Selain itu 
dalam pengenalan awal ini guru dapat mendorong siswa agar terlibat dalam aktivitas pemecahan masalah.

b. Mengorganisasi siswa untuk belajar.

Guru dapat membuat tugas belajar masing-masing siswa dalam kelompok dengan mengidentifikasi dan mengorganisasikan masalah tersebut (menetapkan topik, tugas, jadwal, pelaksanaan, dan lain-lain)

c. Membimbing penyelidikan masalah yang dihadapi individu maupun kelompok.

Kegiatan ini dapat dilakukan berkelompok atau individu masing-masing. Guru hanya bertugas membimbing dan mengarahkan siswa untuk mengumpulkan informasi yang sesuai, melaksanakan kegiatan pembelajaran yang memberikan tantangan untuk mendapatkan penjelasan dan pemecahan masalah, pengumpulan data, hipotesis, dan hasil pemecahan masalah.

d. Mengembangkan dan menyajikan hasil karya.

Kegiatan yang dilakukan guru dapat membantu siswa dalam merencanakan serta menyiapkan karya yang ingin disajikan dari kelompok hasil dari diskusinya.

e. Menganalisa dan mengevaluasi proses pemecahan masalah.

Karya yang telah diujukan dianalisis bersama seluruh siswa, serta guru memberikan refleksi (evaluasi) dari pemecahan masalah yang dianalisis tersebut.

Perkembangan berpikir siswa MI/SD dalam pemecahan masalah mulai dengan pemecahan masalah satu langkah, dua langkah dan banyak langkah dengan disertai kemampuan memahami dan menangakap variabel dan faktor dari masalah. Menurut Winarni dan Harmini (2016: 124-127), ada beberapa cara yang dapat digunakan membantu guru dalam mengajarkan pemecahan masalah kepada siswa antara lain:

a. Membantu siswa agar mampu memecahkan masalah, dengan cara memberikan masalah pada setiap jam pelajaran matematika setiap hari. Dengan demikian, siswa terlatih untuk membaca masalah, menjawab pertanyaan yang berkaitan dengan pemahaman masalah, merencanakan strategi pemecahan masalah, memecahkan masalah, dan untuk melihat kembali apakah jawaban dan interpretasi dari masalah tersebut sudah benar.

b. Menyajikan aktivitas untuk memecahkan masalah.

Hal ini dapat dilakukan dengan membaca masalah secara individu, menyajikan masalah tanpa menggunakan bilangan, memberikan masalah 
kepada siswa tanpa mencantumkan apa yang ditanyakan dan siswa diminta merumuskan pertanyaan yang dimaksud, memberikan masalah yang tidak disertai data yang lengkap dan siswa diminta merumuskan apa yang diketahui, dan terakhir memberikan masalah dengan disertai data yang berlebih, sehingga siswa dituntut untuk dapat menganalisis data mana yang diperlukan untuk memecahkan masalahnya.

\section{Kemampuan Pemahaman Konsep Soal Cerita Matematika}

Pentingnya kemampuan pemahaman konsep matematika termaktub dalam Pemendiknas No. 22 Tahun 2006 (Herawati, 2010: 4) yang menyatakan bahwa tujuan pertama pembelajaran matematika yaitu memahami konsep matematika, menjelaskan keterkaitan antarkonsep dan mengaplikasikan konsep secara luwes, akurat, efisien dan tepat dalam pemecahan masalah. Sesuai dengan tujuan pembelajaran matematika di atas setelah proses pembelajaran matematika diharapkan siswa dapat memahami suatu konsep matematika sehingga dapat menggunakan kemampuan tersebut dalam menghadapi masalah-masalah matematika. Jadi dapat dikatakan bahwa pemahaman konsep merupakan bagian yang paling penting dalam pembelajaran matematika.

Pemahaman adalah memahami makna dan penafsiran, seperti mampu mengidentifikasi contoh-contoh bentuk dan tahapan dalam kutipan-kutipan tertulis (Eggen \& Kauchak, 2016: 10). Hasil belajar sebagai bagian dari kurikulum terdiri atas berbagai domain, seperti pengetahuan, keterampilan, sikap dan nilainilai. Secara teoritis, domain hasil belajar tersebut dapat dipisahkan, tetapi secara praktis, domain tersebut harus bersatu. Hasil belajar juga banyak dipengaruhi oleh berbagai faktor diantaranya, guru, peserta didik, sumber belajar, dan lingkungan (Arifin, 2014: 11).

Sedangkan konsep adalah ide nyata yang digunakan untuk menggolongkan atau mengkategorikan sekumpulan objek, apakah objek tersebut merupakan contoh atau bukan contoh (Fathani, 2009: 61). Konsep pada umumnya dipelajari dengan salah satu dari dua cara, yaitu pengamatan dan definisi. Kebanyakan yang dipelajari di luar sekolah, dipelajari melalui pengamatan. Misalnya anak mempelajari konsep "mobil" dengan mendengarkan kendaraan tertentu yang disebut "mobil". Konsep lain biasanya dipelajari melalui definisi misalnya sangat sulit memelajari konsep "tante" dan "paman" hanya melalui pengamatan saja. Dalam kasus ini definisi menjadi pemahaman yang paling baik. Dengan definisi, contoh dan bukan contoh dapat dibedakan dengan cepat. Pengajaran konsep meliputi contoh yang luas dan terampil. Tennyson dan Park (Slavin, 2017: 301- 
302) mengusulkan agar guru dapat mengikuti tiga aturan ketika menyajikan contoh konsep :

a. Mengurutkan contoh-contoh dari mudah hingga sulit

b. Memilih contoh yang berbeda satu dari yang lain

c. Membandingkan dan membedakan contoh dan bukan contoh.

Menurut Heruman (2017: 3) pemahaman konsep adalah pembelajaran lanjutan dari penanaman konsep, yang bertujuan agar siswa lebih memahami suatu konsep matematika. Pemahaman konsep terdiri dari dua pengertian: Pertama, merupakan kelanjutan dari pembelajaran penanaman konsep dalam satu pertemuan. Kedua, pembelajaran pemahaman konsep dilakukan pada pertemuan yang berbeda, tetapi masih lanjutan dari penanaman konsep. Pada pertemuan tersebut penanaman konsep dianggap sudah disampaikan pada pertemuan sebelumnya, di semester atau kelas sebelumnya. Kemampuan pemahaman matematis adalah kemampuan menyerap dan memahami ide-ide matematika. Sedangkan pemahaman sendiri dibagi menjadi beberapa aspek, salah satunya pemahaman konsep.

Menurut Kilpatrik (Lestari dan Yudhanegara, 2017: 81) kemampuan pemahaman konsep adalah kemampuan yang berkenaan dengan memahami matematika yang menyeluruh dan fungsional. Adapun indikator kemampuan pemahaman konsep matematis yaitu:

a. Menyatakan ulang konsep yang telah dipelajari;

b. Mengklasifikasikan objek-objek berdasarkan konsep matematika;

c. Menerapkan konsep secara algoritma;

d. Memberikan contoh atau kontra contoh dari konsep yang dipelajari;

e. Menyajikan konsep dalam berbagai representasi dan;

f. Mengaitkan berbagai konsep matematika secara internal atau eksternal.

Menurut Winarni dan Harmini (2016: 122) soal cerita merupakan rangkaian kata-kata atau rangkaian kalimat yang mengandung konsep matematika. Soal cerita merupakan soal matematika yang diungkapkan atau dinyatakan dengan kata-kata atau kalimat dalam bentuk cerita yang dikaitkan denga kehidupan sehari-hari. Jadi kemampuan pemahaman konsep soal cerita matematika adalah kemampuan pengetahuan siswa untuk memahami secara dasar dan mendalam tentang soal yang berwujud kalimat. Pemahaman konsep soal cerita ini, memungkinkan siswa untuk memahami kegunaan matematika dalam kehidupan sehari-hari siswa. Sehingga tidak hanya secara teori saja, namun siswa dapat memahami dan memanfaatkan secara praktik aplikasi matematika di kehidupannya. 
Jadi, kemampuan pemahaman konsep soal cerita matematika adalah kemampuan pengetahuan siswa untuk memahami secara dasar dan mendalam tentang soal yang berwujud kalimat. Pemahaman konsep soal cerita ini, memungkinkan siswa untuk memahami kegunaan matematika dalam kehidupan sehari-hari siswa. Sehingga tidak hanya secara teori saja, namun siswa dapat memahami dan memanfaatkan secara praktik aplikasi matematika di kehidupannya.

\section{Materi Volume Balok}

Matematika adalah cermin peradaban manusia. Kehidupan sehari-hari matematika merupakan pembelajaran yang sangat penting. Tidaklah berlebihan jika dikatakan bahwa sejarah matematika adalah sejarah peradaban manusia. Matematika merupakan pengetahuan mengenai kuantitas dan ruang, salah satu cabang dari sekian banyak cabang ilmu yang sistematis, teratur dan eksak. Matematika sendiri merupakan angka-angka dan perhitungan yang merupakan bagian hidup manusia, menolong manusia menafsirkan secara eksak berbagai ide dan kesimpulan serta membahas tentang berbagai problem ruang dan waktu di sekitar manusia (Fathani, 2009: 24-25).

Salah satu materi pembelajaran matematika yang memuat kehidupan sehari-hari siswa adalah volume balok. Volume artinya isi atau banyak benda dalam ruang. Banyaknya air dalam gelas dan banyak pasir dalam botol dinamakan volume. Satuan volume yaitu $\mathrm{km}^{3}, \mathrm{~m}^{3}, \mathrm{dm}^{3}$, dan $\mathrm{cm}^{3}$. Bangun ruang memiliki volume, salah satunya balok (Nurhaini dan Priyanto, 2016: 120).

Berikut merupakan materi volume balok yaitu :

\section{Bangun ruang balok}

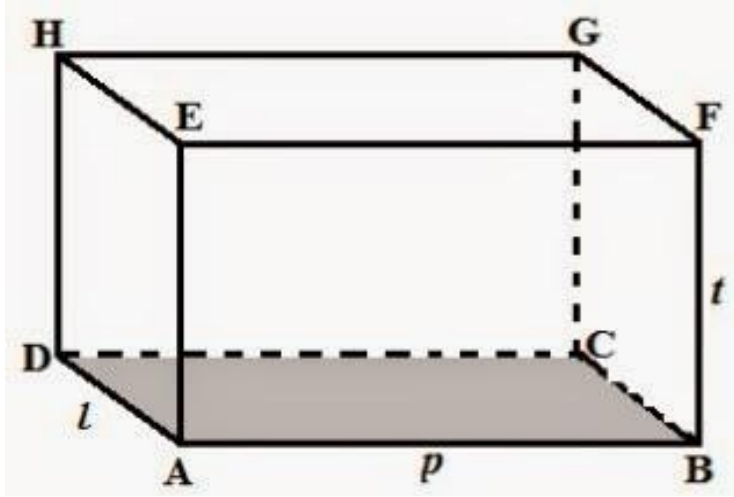

Gambar 1 Balok ABCDEFGH

Dalam gambar 1, ciri-ciri balok adalah

- Memiliki 6 sisi 
- Memiliki 3 sisi berpasangan

- Memiliki 12 rusuk

- Memiliki 8 titik sudut

panjang balok $=p$, lebar balok $=l$, dan tinggi balok $=t$. maka volumenya dapat dirumuskan sebagai berikut :

\section{Volume balok $=p \times \boldsymbol{l} \times \boldsymbol{t}$}

Berikut ini merupakan gambar jaring-jaring balok, sebagai berikut :

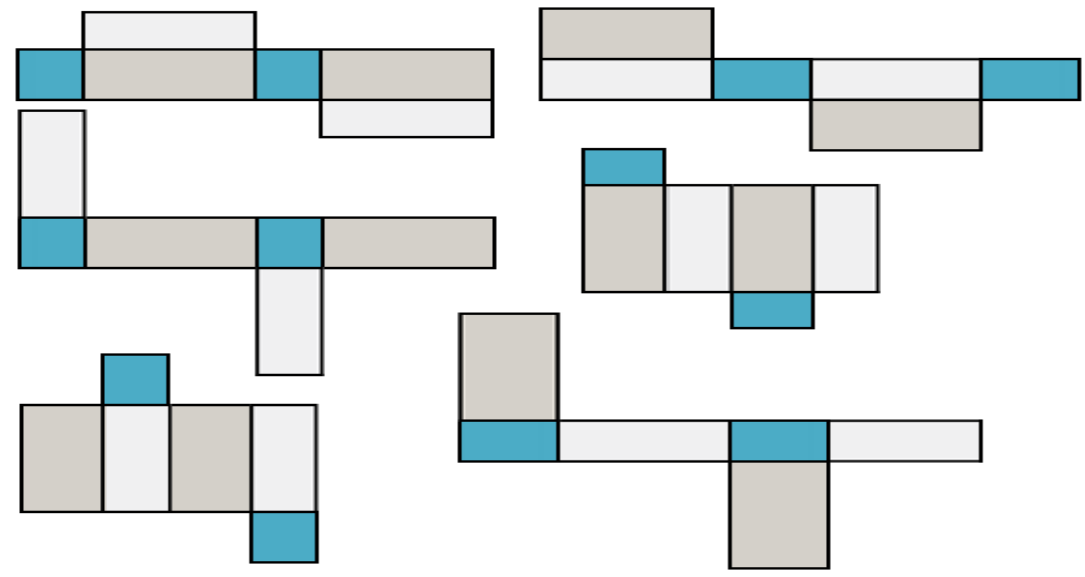

Gambar 2 Jaring-jaring Balok

\section{Contoh soal cerita volume balok sebagai berikut:}

Sebuah wadah berbetuk balok memiliki panjang $5 \mathrm{dm}$, lebar $2 \mathrm{dm}$ dan tinggi $4 \mathrm{dm}$. Wadah tersebut diisi bensin hingga penuh. Harga bensin Rp. 15.000 setiap liter. Berapa harga bensin dalam wadah tersebut?

\section{Penyelesaian:}

Diketahui :

$\mathrm{p}=5 \mathrm{dm}, \mathrm{l}=2 \mathrm{dm}, \mathrm{t}=4 \mathrm{dm}$

Harga bensin = Rp. 15.000,- per liter

Ditanya :

Harga bensin dalam wadah....?

Dijawab :

Volume wadah $=\mathrm{p} \times \mathrm{l} \times \mathrm{t}=5 \times 1 \times 4=40$ liter

Harga bensin dalam wadah $=40 \times$ Rp. 15.000,- $=$ Rp. 600.000

Jadi harga bensin dalam wadah tersebut adalah Rp. 600.000,-

\section{Penyajian Data}

Hasil penelitian berupa deskripsi data pretest dan posttest. Hasil data dapat dilihat pada tabel berikut ini :

Tabel 1 Data Pretest Kelas Eksperimen dan Kelas Kontrol 


\begin{tabular}{|clcc|}
\hline \multirow{2}{*}{ No } & \multirow{2}{*}{ Kriteria Data } & \multicolumn{2}{c|}{ Data Pretest Siswa } \\
\cline { 3 - 4 } & Kontrol & Eksperimen \\
\hline 1 & Jumlah Siswa & 31 & 31 \\
\hline 2 & Skor rata-rata & 31.323 & 53.548 \\
\hline 3 & Simpangan baku & 12.265 & 18.495 \\
\hline 4 & Varians & 150.426 & 342.056 \\
\hline 5 & Skor Minimal & 10 & 20 \\
\hline 6 & Skor Maksimal & 62 & 92 \\
\hline 7 & $\begin{array}{l}\text { Hasil Uji } \\
\text { Normalitas }\end{array}$ Uji & 0.092 & 0.200 \\
\hline 8 & $\begin{array}{l}\text { Hasil } \\
\text { Homogenitas }\end{array}$ \\
\hline
\end{tabular}

Berdasarkan tabel 1 menunjukkan bahwa kelas kontrol berjumlah 31 siswa dengan skor rata-rata sebesar 31,3 dan kelas eksperimen berjumlah 31 siswa dengan skor rata-rata 53.5. Data kedua kelas normal signifikasi data pretest $0.092>0.05$ dan $0.200>$ 0.05 . Uji homogenitas data pretest kedua variansi homogen $0.056>0.05$. Distribusi frekuensi skor nilai pretest dapat dilihat dalam histogram berikut ini:

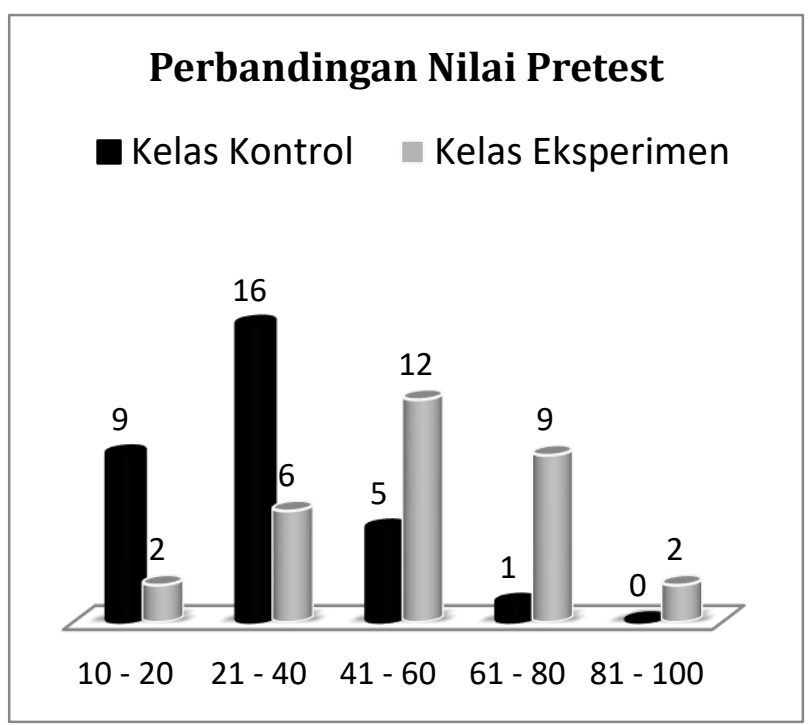

Grafik 1 Perbandingan Nilai Pretes Kelas Kontrol dan Kelas Eksperimen

Data post-test kelas kontrol dan kelas eksperimen dilaksanakan pada akhir setelah pembelajaran matematika sebagai berikut: 
Tabel 2 Data Post-test Kelas Eksperimen dan Kelas Kontrol

\begin{tabular}{|clcc|}
\hline \multirow{2}{*}{ No } & \multirow{2}{*}{ Kriteria Data } & \multicolumn{2}{c|}{ Data Posttest Siswa } \\
\cline { 3 - 4 } & & Kontrol & Eksperimen \\
\hline 1 & Jumlah Siswa & 31 & 31 \\
\hline 2 & Skor rata-rata & 52.806 & 81.548 \\
\hline \multirow{2}{*}{3} & $\begin{array}{l}\text { Simpang-an } \\
\text { baku }\end{array}$ & 12.084 & 12.824 \\
\hline 4 & Varians & 146.028 & 164.456 \\
\hline 5 & Skor Minimal & 30 & 50 \\
\hline 6 & Skor Maksimal & 72 & 100 \\
\hline 7 & Uji Normalitas & 0.064 & 0.200 \\
\hline \multirow{2}{*}{8} & $\begin{array}{l}\text { Uji } \\
\text { Homogenitas }\end{array}$ & \multicolumn{2}{|c|}{0.981} \\
\hline
\end{tabular}

Berdasarkan tabel 2 menunjukkan bahwa kelas kontrol berjumlah 31 siswa dengan skor rata-rata sebesar 52.86 dan kelas eksperimen berjumlah 31 siswa dengan skor rata-rata 81.548. Data kedua kelas normal signifikasi data posttest $0.064>0.05$ dan $0.200>0.05$. Uji homogenitas data posttest kedua variansi homogen $0.981>0.05$.

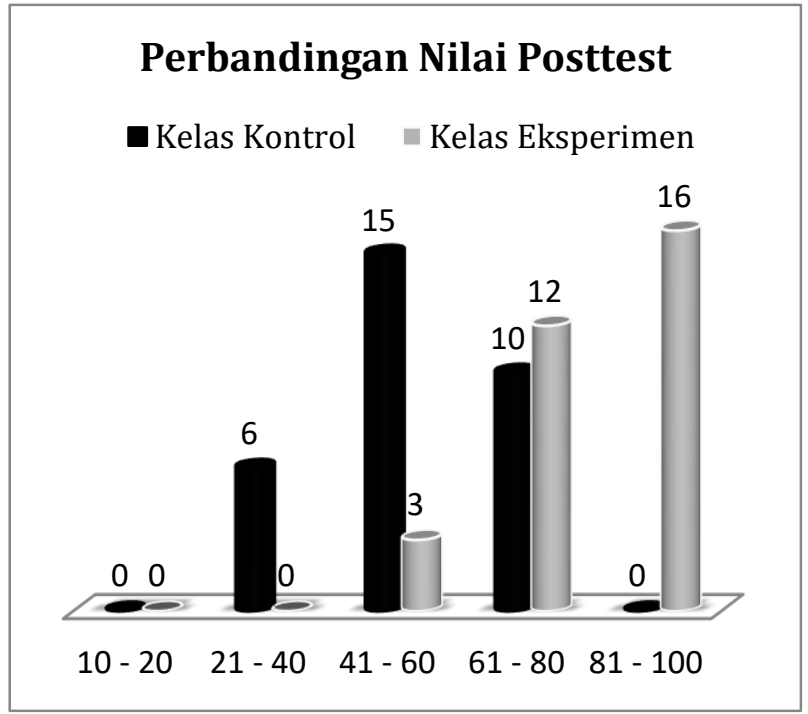

Grafik 2 Perbandingan Nilai Posttest Kelas Kontrol dan Kelas Eksperimen

Pengujian hipotesis dengan Uji-t (Paired Samples t-test) data pretest dan posttest pada kelas kontrol dan kelas eksperimen. Data pretest dan posttest kelas kontrol setelah diujikan menggunakan aplikasi SPSS 22.0 uji-t paired samples t-test terdapat pengaruh dari perlakukan pembelajaran. 
Tabel 3 Uji Paired Samples t-test Kelas Kontrol

Paired Samples Test

\begin{tabular}{|c|c|c|c|c|c|c|c|c|}
\hline & \multicolumn{5}{|c|}{ Paired Differences } & \multirow[b]{3}{*}{$\mathrm{T}$} & \multirow[b]{3}{*}{ Df } & \multirow{3}{*}{$\begin{array}{l}\text { Sig. } \\
(2- \\
\text { tailed) }\end{array}$} \\
\hline & \multirow[b]{2}{*}{ Mean } & \multirow{2}{*}{$\begin{array}{c}\text { Std. } \\
\text { Deviation }\end{array}$} & \multirow{2}{*}{$\begin{array}{l}\text { Std. } \\
\text { Error } \\
\text { Mean }\end{array}$} & \multicolumn{2}{|c|}{$\begin{array}{l}\text { 95\% Confidence } \\
\text { Interval of the } \\
\text { Difference }\end{array}$} & & & \\
\hline & & & & Lower & Upper & & & \\
\hline $\begin{array}{ll}\text { Pair } 1 & \text { Pretest - } \\
& \text { Posttest }\end{array}$ & -21.484 & 12.393 & 2.226 & -26.030 & -16.938 & -9.652 & 30 & .000 \\
\hline
\end{tabular}

Berdasarkan tabel 3 di atas dapat dilihat jika nilai signifikansi $<0.05$ maka $\mathrm{H}_{0}$ ditolak dan $\mathrm{H}_{1}$ diterima. Jika sebaliknya nilai signifikansi $>0.05$ maka $\mathrm{H}_{0}$ diterima dan $\mathrm{H}_{1}$ ditolak. Jadi pada tabel diatas nilai signifikansi (sig. (2-tailed) $=0.000<0.05$ dan $t_{\text {hitung }}$ sebesar -9.652 berarti terdapat pengaruh pada data pretest dan posttest kelas kontrol.

Pengujian data pretest dan posttest kelas eksperimen setelah diujikan menggunakan aplikasi SPSS 22.0 uji-t paired samples t-test terdapat pengaruh dari perlakukan pembelajaran.

Tabel 4 Uji Paired Samples t-test Kelas Eksperimen

\section{Paired Samples Test}

\begin{tabular}{|c|c|c|c|c|c|c|c|c|}
\hline & \multicolumn{5}{|c|}{ Paired Differences } & \multirow[b]{3}{*}{$\mathrm{T}$} & \multirow[b]{3}{*}{$\mathrm{df}$} & \multirow{3}{*}{$\begin{array}{l}\text { Sig. (2- } \\
\text { tailed) }\end{array}$} \\
\hline & \multirow[b]{2}{*}{ Mean } & \multirow{2}{*}{$\begin{array}{c}\text { Std. } \\
\text { Deviation }\end{array}$} & \multirow{2}{*}{$\begin{array}{l}\text { Std. } \\
\text { Error } \\
\text { Mean }\end{array}$} & \multicolumn{2}{|c|}{$\begin{array}{l}\text { 95\% Confidence } \\
\text { Interval of the } \\
\text { Difference }\end{array}$} & & & \\
\hline & & & & Lower & Upper & & & \\
\hline $\begin{array}{ll}\mathrm{Pa} & \text { Pretest - } \\
\text { ir } & \text { Posttest } \\
1 & \\
\end{array}$ & -28.000 & 15.067 & 2.706 & -33.526 & -22.474 & -10.347 & 30 & .000 \\
\hline
\end{tabular}

Berdasarkan tabel 4 dapat dilihat jika nilai signifikansi $<0.05$ maka $\mathrm{H}_{0}$ ditolak dan $\mathrm{H}_{1}$ diterima. Jika sebaliknya nilai signifikansi $>0.05$ maka $\mathrm{H}_{0}$ diterima dan $\mathrm{H}_{1}$ ditolak. Jadi pada tabel diatas nilai signifikansi (sig. (2-tailed) $=0.000<$ 0.05 dan thitung 10.347 berarti terdapat pengaruh pada data pretest dan posttest kelas eksperimen.

Pengujian hipotesis dengan Uji-t (Independent Samples t-test), pengujian ini dilakukan untuk mengetahui apakah ada pengaruh dari perlakuan kelas kontrol dan kelas eksperimen yang menggunakan metode problem solving dengan metode 
konvensional terhadap kemampuan pemahaman konsep soal cerita. Dari data posttest diujikan menggunakan uji t (Independent Samples t-test) diperoleh data berikut:

Tabel 5 Uji Independent Samples t-test Data Posttest

Independent Samples Test

\begin{tabular}{|c|c|c|c|c|c|c|c|c|c|c|}
\hline & \multicolumn{2}{|c|}{$\begin{array}{c}\text { Levene's } \\
\text { Test for } \\
\text { Equality } \\
\text { of } \\
\text { Variances }\end{array}$} & \multicolumn{7}{|c|}{ t-test for Equality of Means } \\
\hline & & \multirow[b]{2}{*}{$\mathrm{F}$} & \multirow[b]{2}{*}{ Sig. } & \multirow[b]{2}{*}{$\mathrm{T}$} & \multirow[b]{2}{*}{ Df } & \multirow{2}{*}{$\begin{array}{l}\text { Sig. } \\
(2- \\
\text { tailed } \\
\quad \text { ) }\end{array}$} & \multirow{2}{*}{$\begin{array}{c}\text { Mean } \\
\text { Differenc } \\
\mathrm{e}\end{array}$} & \multirow{2}{*}{$\begin{array}{c}\text { Std. } \\
\text { Error } \\
\text { Differenc } \\
\text { e }\end{array}$} & \multicolumn{2}{|c|}{$\begin{array}{c}\text { 95\% Confidence } \\
\text { Interval of the } \\
\text { Difference }\end{array}$} \\
\hline & & & & & & & & & Lower & Upper \\
\hline $\begin{array}{l}\text { Hasil } \\
\text { Belajar } \\
\text { Siswa }\end{array}$ & $\begin{array}{l}\text { Equal } \\
\text { variance } \\
\text { s } \\
\text { assumed } \\
\text { Equal } \\
\text { variance } \\
\text { s not } \\
\text { assumed }\end{array}$ & $\begin{array}{r}.00 \\
1\end{array}$ & $\begin{array}{r}.98 \\
1\end{array}$ & $\begin{array}{r}- \\
9.08 \\
2 \\
\\
- \\
9.08 \\
2\end{array}$ & $\begin{array}{r}59.78 \\
9\end{array}$ & .000 & -28.742 & 3.165 & $\begin{array}{r}- \\
35.07 \\
2 \\
\\
- \\
35.07 \\
3\end{array}$ & -22.411 \\
\hline
\end{tabular}

Berdasarkan tabel 5 dapat dilihat jika nilai signifikansi $<0.05$ maka $\mathrm{H}_{0}$ ditolak dan $\mathrm{H}_{1}$ diterima. Jika sebaliknya nilai signifikansi $>0.05$ maka $\mathrm{H}_{0}$ diterima dan $\mathrm{H}_{1}$ ditolak. Jadi pada tabel diatas nilai signifikansi (sig. (2-tailed) $=0.000<$ 0.05 berarti terdapat pengaruh yang signifikan penerapan metode problem solving terhadap kemampuan pemahamann konsep soal cerita siswa. Nilai rata-rata (mean) pada kelas eksperimen sebesar 81,548 lebih tinggi dari pada kelas kontrol sebesar 52,806 dan thitung -9.082 yang bernilai negative, artinya terdapat perbedaan yang signifikan rata-rata kelas eksperimen dengan kelas kontrol . Maka terdapat pengaruh metode problem solving terhadap kemampuan pemahaman konsep soal cerita siswa kelas $\mathrm{V}$ pada materi volume balok. Untuk mengetahui seberapa besar pengaruh metode problem solving terhadap kemampuan pemahaman konsep soal cerita matematika digunakan rumus dibawah ini: 


$$
\begin{aligned}
Y & =\frac{\overline{X_{1}}-\overline{X_{2}}}{\bar{X}_{2}} \times 100 \% \\
Y & =\frac{81.548-52.806}{52.806} \times 100 \% \\
Y & =0.54429 \times 100 \% \\
Y & =54 \%
\end{aligned}
$$

Dari hasil penghitungan di atas dapat diketahui bahwa besarnya pengaruh metode problem solving terhadap kemampuan pemahaman konsep soal cerita materi volume balok siswa kelas V sebesar 54\% yaitu termasuk dalam kategori sedang.

Prosentase pencapaian indikator kemampuan pemahaman konsep soal cerita dibuktikan dengan histogram dibawah ini :

\section{Tabel 6 Indikator Kemampuan Pemahaman Konsep Soal Cerita}

\begin{tabular}{|l|c|c|}
\hline \multicolumn{1}{|c|}{ Kemampuan } & $\begin{array}{c}\text { Kelas } \\
\text { Eksperimen }\end{array}$ & $\begin{array}{c}\text { Kelas } \\
\text { Kontrol }\end{array}$ \\
\hline $\begin{array}{l}\text { Menyatakan ulang } \\
\text { konsep yang telah } \\
\text { dipelajar }\end{array}$ & $83 \%$ & $67 \%$ \\
\hline $\begin{array}{l}\text { Mengklasifikasikan } \\
\text { objek-objek } \\
\text { berdasarkan konsep } \\
\text { matematika }\end{array}$ & $79 \%$ & $64 \%$ \\
\hline $\begin{array}{l}\text { Menerapkan konsep } \\
\text { secara sesuai dengan } \\
\text { tahapan }\end{array}$ & $79 \%$ & $48 \%$ \\
\hline $\begin{array}{l}\text { Memberikan contoh } \\
\text { atau kontra contoh dari } \\
\text { konsep yang dipelajari }\end{array}$ & $78 \%$ & $31 \%$ \\
\hline $\begin{array}{l}\text { Menyajikan konsep } \\
\text { dalam berbagai } \\
\text { representasi }\end{array}$ & $81 \%$ & $55 \%$ \\
\hline $\begin{array}{l}\text { Mengaitkan berbagai } \\
\text { konsep matematika } \\
\text { secara internal atau } \\
\text { eksternal }\end{array}$ & $78 \%$ & $39 \%$ \\
\hline \multicolumn{1}{|c|}{ Rata-rata } & $\mathbf{8 0 \%}$ & $\mathbf{5 1 \%}$ \\
\hline
\end{tabular}

Berdasarkan tabel 6 di atas juga menunjukkan bahwa kemampuan pemahaman konsep soal cerita menggunakan metode problem solving lebih baik daripada menggunakan metode konvensional (ceramah). Rata-rata pencapaian indikator kelas eksperimen lebih tinggi sebesar 80\% dibandingkan kelas kontrol sebesar 51\%. Penerapan metode problem solving lebih berpengaruh dari pada 
metode ceramah. Penerapan metode problem solving membuat siswa lebih aktif di dalam pembelajaran, membuat siswa diskusi dengan masalah yang ada di kehidupan sehari-hari. Meskipun waktu dan pemberian materi sama, namun penerapan metode problem solving lebih mengena dimana siswa lebih aktif dalam pembelajaran. Hal ini sesuai dengan teori Pieget bahwa siswa dapat memahami pengetahuan melalui konsep-konsep yang ada pada lingkungan sekitarnya, sehingga proses pembelajaran lebih menarik karena siswa dapat berfikir sesuai dengan apa yang diketahuinya.

\section{SIMPULAN}

Berdasarkan hasil yang diperoleh dari analisis data dan keterangan sebelumnya dapat ditarik kesimpulan sebagai berikut :

1. Metode problem solving mempengaruhi kemampuan pemahaman konsep soal cerita siswa kelas V MI An-Nashriyah Lasem Rembang. Berdasarkan hasil pengujian hipotesis menggunakan independent samples t-test menggunakan aplikasi SPSS 22.0 diperoleh taraf signifikansi $(0.000<0.05)$ pada lembar instrument tes. Rata-rata kelas eksperimen diperoleh 81,54 dan kelas kontrol diperoleh 52,80.

2. Pengaruh metode problem solving terhadap kemampuan pemahaman konsep soal cerita materi volume balok pada kelas V di MI An-Nashriyah Lasem Rembang sebesar $54 \%$ kategori sedang.

Disarankan bagi pendidik untuk menerapkan metode problem solving sebagai alternatif dan tindak lanjut dalam pembelajaran matematika terhadap kemampuan pemahaman konsep soal cerita.

\section{E. DAFTAR RUJUKAN}

Arifin, Zainal. (2014). Konsep dan Model Pengembangan Kurikulum. Bandung: PT Remaja Rosdakarya.

Djamarah, Syaiful Bahri; Zain, Aswan. (2014). Strategi Belajar Mengajar. Jakarta: PT Rineka Cipta.

Eggen, Paul; Kauchak, Don. (2016). Strategie and Models for Teachers: Teaching Content and Thingking Skills, Sixth Edition, Terj. Satrio Wahono. Jakarta: Indeks.

Fathani, Abdul Halim. (2009). Matematika Hakikat dan Logika. Yogyakarta: ArRuzz Media. 
Hamdani. (2011). Strategi Belajar Mengajar. Bandung: Pustaka Setia.

Herawati, Oktiana Dwi Putra. Juni (2010). "Pengaruh Pembelajaran Problem Posing Terhadap Kemampuan Pemahaman Konsep Matematika Siswa Kelas XI IPA SMA N 6 Pemalang”. Jurnal Pendidikan Matematika. Vol. 4, No.1

Heruman. (2017). Model Pembelajaran Matematika di Sekolah Dasar. Bandung: PT Remaja Rosdakarya.

Lestari, Karunia Eka; Yudhanegara, Mokhamad Ridwan. (2017). Penelitian Pendidikan Matematika. Bandung: PT Refika Aditama.

Ngalimun. (2017). Strategi Pembelajaran. Yogyakarta: Parama Ilmu.

Nurhaini, Dewi; Priyanto, Sulis. 2016. Buku Siswa Mari Belajar Matematika 5 Pendidikan Matematika. Surakarta: CV Usaha Makmur.

Slavin, Robert E.. (2017). Educational Psychology:Theory and Practice, Terj. Marianto Samosir. Jakarta: PT Indeks.

Sudjana. 2005. Metode Statistika. Bandung: Tarsito.

Sugiyono. (2017). Statistika Untuk Penelitian. Bandung: Alfabeta.

Sugiyono. (2017). Metode Penelitian dan Pengembangan Research and Development. Bandung: Alfabeta.

Sugiyono. (2015). Metode Penelitian. Bandung: Alfabeta.

Trianto. (2010). Mendesain Model Pembelajaran Inovatif Progresif. Jakarta: Kencana.

Winarni, Endang Setyo; Harmini, Sri. (2016). Matematika Untuk PGSD. Bandung: PT Remaja Rosdakarya. 